\title{
Responsible pet ownership perception in elementary schools after an educational program in Southern Brazil
}

\section{Percepção dos alunos de ensino fundamental sobre guarda responsável de animais após um programa de educação no sul do Brasil}

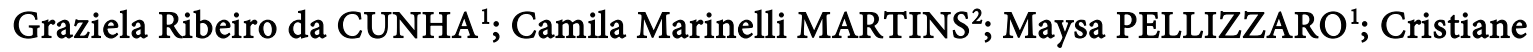 \\ Conceição de BARROS ${ }^{3}$; Raquel Santos PAMPUCH ${ }^{3}$; Antônio Felipe Paulino de Figueiredo WOUK ${ }^{1}$; \\ Fernando FERREIRA ${ }^{2}$; Rita de Cássia Maria GARCIA ${ }^{1}$; Alexander Welker BIONDO ${ }^{1}$ \\ ${ }^{1}$ Universidade Federal do Paraná, Curitiba - PR, Brazil \\ ${ }^{2}$ Universidade de São Paulo, Faculdade de Medicina Veterinária e Zootecnia, Departamento de Medicina Veterinária Preventiva e \\ Saúde Animal, São Paulo - SP, Brazil \\ ${ }^{3}$ Prefeitura de Pinhais, Pinhais - PR, Brazil
}

\begin{abstract}
The impact of responsible ownership programs with the goal of promoting public health remains to be fully established in Brazil. This study aimed to evaluate the responsible pet ownership perception of public elementary school students and teachers after a four-year outreach educational program in the city of Pinhais, Southern Brazil. Questionnaires were distributed for self-answer by fourth-grade students and teachers of all city public elementary schools. A total of 1,022/1,332 students (76.7\%) referred participated in the program. No significant differences were observed between participating and nonparticipating groups regarding the concepts of responsible ownership $(\mathrm{p}=0.88)$, zoonoses $(\mathrm{p}=0.09)$ and animal welfare $(\mathrm{p}=$ 0.94). However, the frequency of correct answers on responsible ownership and zoonoses concepts was significantly higher ( $\mathrm{p}$ $<0.01)$ among student groups who participated 1 or 2 times $(779 / 830 ; 93.8 \%$ and 506/813; 62.2\%, respectively) in relation to the groups that participated $>2$ times $(144 / 165 ; 87.3 \%$ and $64 / 151 ; 42.4 \%$, respectively). It was also significantly higher ( $\mathrm{p}<$ $0.01)$ between $\leq 10$ years group $(991 / 1058,93.7 \%)$ compared to group $>10$ years $(158 / 180 ; 87.8 \%)$ in the first concept. Although most teachers approved the continuing program (128/137; 93.4\%), they reported low rates on training participation (41/137; $29.9 \%)$ and use of available teaching materials $(78 / 137 ; 26.9 \%)$. The study has shown that perception of responsible pet ownership in outreach education programs may be more easily absorbed by children under ten years of age and up to two participations.
\end{abstract}

Keywords: Pets. Responsible ownership. Students. Education.

\section{Resumo}

O impacto de programas de guarda responsável que objetivam promover a saúde pública precisa ser plenamente estabelecido no Brasil. Este estudo objetivou avaliar a percepção sobre guarda responsável de animais de estudantes do ensino fundamental e professores após um programa com quatro anos de duração na cidade de Pinhais. Questionários foram distribuídos para alunos da quarta série e professores de todas as escolas públicas de ensino fundamental da cidade. No total, 1022/1332 estudantes $(76,7 \%)$ participaram do programa. Não houve diferença significativa entre os grupos que participaram e não participaram, em relação aos conceitos de guarda responsável $(\mathrm{p}=0,88)$, zoonoses $(\mathrm{p}=0,09)$ e bem-estar animal $(\mathrm{p}=0,94)$. Entretanto, a frequência de acertos dos conceitos de guarda responsável e zoonoses foi significativamente maior ( $\mathrm{p}<0,01$ ) entre os estudantes do grupo que participou 1 ou 2 vezes (779/830; 93,8\% e 506/813; 62,2\%, respectivamente) com relação ao grupo que participou $>2$ vezes $(144 / 165 ; 87,3 \%$ e $64 / 151 ; 42,4 \%$, respectivamente). E também foi significativamente maior ( $\mathrm{p}<$ 0,01) entre o grupo $\leq 10$ anos (991/1058; 93.7\%) com relação ao grupo > 10 anos (158/180; 87,8\%) no primeiro conceito. Apesar da maioria dos professores aprovarem a continuidade do programa (128/137; 93,4\%), eles reportaram baixas taxas de participação no treinamento $(41 / 137 ; 29,9 \%)$ e utilização dos materiais didáticos disponíveis (78/137; 26,9\%). O estudo mostrou que a percepção sobre guarda responsável de animais em programas de educação continuada pode ser mais facilmente absorvida por crianças de até 10 anos de idade e com até duas participações.

Palavras-chave: Animais de estimação. Guarda responsável. Alunos. Educação. 
Correspondence to:

Graziela Ribeiro da Cunha

Rua dos Funcionários, 1540

CEP 80035-050, Curitiba, PR, Brazil

E-mail: graziela.ribeiro@ufpr.br

Received: 19/10/2015

Approved: 06/04/2016

\section{Introduction}

The promotion of responsible pet ownership associated with educational activities may be one of the most important strategies for effective population management and relinquishment prevention of companion animals (GARCIA et al., 2012). Since education may produce habit changing and knowledge multipliers (MAGALHÃES et al., 2009), outreach programs associating healthcare with cruelty prevention may create a more humane and pet-friendly community. Responsible ownership programs may also improve human-animal interactions and animal welfare, reducing animal risks to other animals, households and communities. Furthermore, good experiences with pets during childhood may have positive impact and lifetime implications (PODBERSCEK, 2006; WESTGARTH et al., 2013).

A growing worldwide demand for responsible pet ownership educational programs has been reportedly applied as basis for dog bite (CHAPMAN et al., 2000), zoonosis (BINGHAM et al., 2010) and relinquishment (MOLENTO et al., 2007) prevention, particularly in developing countries. Consequently, most studies have focused on pet population management (MOLENTO et al., 2007; FAVER, 2009) and zoonoses perception and prevention (BINGHAM et al., 2010; STULL et al., 2012) rather than responsible pet ownership itself. Besides, the intervention impact should be accessed and monitored by a long-term program evaluation (COLEMAN et al., 2008). While few studies have applied evaluations on isolated educational actions (COLEMAN et al., 2008; NICOLL et al., 2008), these actions may not be effective due to lack of integration, assessment and/or monitoring.
A truly-effective, low-cost, straightforward and continuous educational model of pet responsible ownership, particularly for elementary schools, even if periodic implementation or adjustments may be further needed, remains to be established. Accordingly, a descriptive transversal study was conducted to evaluate the responsible pet ownership perception of public elementary schools students and teachers after a four-year outreach educational program.

\section{Material and Methods}

This study was conducted in Pinhais, a city of 117,008 inhabitants located within the metropolitan region of Curitiba, the eighth largest city in Brazil with $1,751,907$ habitants in $2010^{1}$. The Pinhais public school system was comprised at the time of 19 elementary schools with approximately 428 teachers and 10,600 students.

The educational program of responsible pet ownership at Pinhais has been annually developed in all public elementary schools since 2006 through a partnership with the Federal University of Parana. Based on a ludic competition known as "Junior Vet", elementary school teachers have been trained before the school year and didactic material provided to students. Throughout the school year, teachers work on selected topics within the classroom and encourage students to participate in the competition. Students producing the best drawings, sentences and essays in each category and classroom are chosen to receive the title of Junior Vet (BARROS et al., 2009). Since 2006, approximately 300 students have won the Junior Vet contest, which has involved more than 30,000 students.

All fourth-grade students ( $\mathrm{n}=1,911$ and minimum representative sampling $=320$ ) were chosen for stratum evaluation as they were the most likely participating group in the Junior Vet at least once since 2006. Likewise, the teachers stratum was selected from all fourthgrade schools $(\mathrm{n}=428$ and minimum representative

${ }^{1}$ Available from: <http://goo.gl/JwBmL0>. Viewed: 24 May 2014. 
sampling $=202)$. Both samples were calculated by a simple random sampling with $95 \%$ confidence and $5 \%$ accuracy.

All teachers were considered to have equal opportunity for training participation before the school year. Questionnaires were prepared in a multiple-choice fashion with the City Secretary of Education, distributed in all schools for self-answer by students and teachers, and collected during the following month.

For students, assessment was objective and included questions on (A) pet ownership; (B) pet-free street access; (C) best living place for a dog, considering "indoors and backyard" as correct; (D) animals have feelings and emotions; (E) responsible pet guardianship concept, considering "give love and protection to pets, taking responsibility for their physical, psychological and environmental needs" as correct; (F) zoonoses concept, considering "diseases that can be transmitted from men to animal or animal to men" as correct; $(\mathrm{G})$ participation on Junior Vet (changes in treating animals after participating, feel more prepared to responsibly care for a pet and have commented with family about the given information). Student answers were compared to whether or not participating on Junior Vet, number of participations ( 1 or 2 times versus 3 times or more) and age ( $\leq 10$ years or $>10$ years).

For teachers, a combination of multiple-choice and ranking questions was used. Multiple-choice included whether or not questions on training participation prior to classroom work, use of teaching material and compliance of continuing program. Ranking questions scoring from 0 to 10 included teacher opinion on Junior Vet importance, other activities on responsible ownership, student opinion and attitude, and overall assessment and difficulties.

All answers were evaluated using the chi-square test (significance level $=0.05$ ) provided by a commercial statistical software (SPSS for windows, version 16.0, SPSS Incorporated, Chicago, IL, USA).

\section{Results}

A total of $17 / 19$ schools (89.0\%) participated in the survey with potentially $1627 / 1911 \quad(85.1 \%)$ and $1332 / 1627$ (81.8\%) questionnaires to be and actually answered by students, respectively (with an average of 78.3 per school). Teachers answered a total of $137 / 428$ (32.0\%) questionnaires with an average of 8.1 per school. Out of 1332 students ranging from 8 to 14 years old, $27(2.0 \%)$ were eight, 375 (28.1\%) nine, 670 (50.3\%) ten, $133(10.0 \%)$ eleven, 37 (2.8\%) twelve, $11(0.8 \%)$ thirteen and $3(0.2 \%)$ were fourteen, with $76(5.8 \%)$ unknown and average age of 9.8 years. Overall, 1063/1332 (79.8\%) were younger and 269/1332 (20.2\%) were older than 10 years of age, respectively.

A total of 1022/1332 (76.7\%) students participated in the program at least once. On average, students participated 1.8 times: 571/1022 (55.9\%) participated once, 263 (25.8\%) twice, 24 (2.4\%) three times, 73 (7.1\%) four times and 64 (6.3\%) five times, while 27 (2.5\%) were unknown. Overall, 834/1022 students (81.6\%) participated once or twice and 188/1022 (18.4\%) participated three or more times.

Questionnaire data regarding pet ownership, free street access, best place for dogs to live, concepts and changes after the Junior Vet, including statistical analyses with age and number of participations groups comparison, are presented in Tables 1 and 2.

Among the teachers, 41/137 (29.9\%) reported having participated in training before working on the subject in the classroom, 78/137 (26.9\%) used the teaching material available and 128/137 (93.4\%) agreed that the program should continue. The teachers considered that the campaigns to encourage responsible ownership and the "Junior Vet" contest were important, with average scores of 9.4 (CI: 9.2-9.6) and 9.0 (CI: 8.8-9.3), respectively. The average rating of students' interest in the program was 8.4 (CI: 8.1-8.8); student's transmission of the issues addressed to other people, 7.8 (CI: 7.5-8.2), personal preparation to work with the content material, 8.1 (CI: 7.8 to 8.5 ); the program as a whole, 8.6 (CI: 8.3 to 8.9 ); and difficulty in carrying out the work, 3.2 (CI: 2.5-3.8). 
Table 1 - Students' perception on animal welfare, zoonoses and responsible ownership, according to their participation in "Junior Vet" and age Pinhais, Paraná - 2010

\begin{tabular}{|c|c|c|c|c|c|c|c|c|c|c|c|c|}
\hline \multirow[b]{3}{*}{ Participated? } & \multicolumn{4}{|c|}{ Animals have feelings and emotions? } & \multicolumn{4}{|c|}{$\begin{array}{c}\text { Do you know what is responsible } \\
\text { ownership? }\end{array}$} & \multicolumn{4}{|c|}{ Do you know what is zoonoses? } \\
\hline & Yes (\%) & No (\%) & Total & $\mathrm{p}$ & Yes (\%) & No (\%) & Total & $\mathrm{p}$ & Yes (\%) & No (\%) & Total & $\mathrm{p}$ \\
\hline & & & & & & & & & & & & \\
\hline Yes & $963(96.0)$ & $40(4.0)$ & 1003 & & $923(92.8)$ & $72(7.2)$ & 995 & & $577(58.9)$ & $402(41.1)$ & 979 & \\
\hline No & $296(96.1)$ & $12(3.9)$ & 308 & 0.94 & $284(92.5)$ & $23(7.5)$ & 307 & 0.88 & $196(64.3)$ & $109(35.7)$ & 305 & 0.09 \\
\hline No Answer ${ }^{a}$ & & & 21 & & & & 30 & & & & 48 & \\
\hline Total & $1259(94.5)$ & $52(5.5)$ & 1332 & & $1207(90.6)$ & $95(9.3)$ & 1332 & & $773(58.1)$ & $511(41.9)$ & 1332 & \\
\hline \multicolumn{13}{|l|}{ Age } \\
\hline$\leq 10$ years & $1020(96.0)$ & $43(4.0)$ & 1063 & & 991 (93.7) & $67(6.3)$ & 1058 & & $643(61.3)$ & $406(38.7)$ & 1049 & \\
\hline$>10$ years & 175 (89.7) & $8(10.3)$ & 183 & 0.84 & $158(87.8)$ & $22(12.2)$ & 180 & 0.005 & $107(60.8)$ & 69 (39.2) & 176 & 0.90 \\
\hline No Answer ${ }^{\mathrm{a}}$ & & & 86 & & & & 94 & & & & 107 & \\
\hline \multirow[t]{3}{*}{ Total } & $1195(94.5)$ & $51(5.5)$ & 1332 & & $1149(86.3)$ & 89 (13.7) & 1332 & & $750(56.3)$ & $475(43.6)$ & 1332 & \\
\hline & \multicolumn{4}{|c|}{ Do you have a dog/cat? } & \multicolumn{4}{|c|}{ Your pet has free street access? } & \multicolumn{4}{|c|}{$\begin{array}{c}\text { Do you know what is the best place for } \\
\text { a dog to live? }\end{array}$} \\
\hline & Yes (\%) & No (\%) & Total & $\mathrm{p}$ & Yes (\%) & No (\%) & Total & $\mathrm{p}$ & Yes (\%) & No (\%) & Total & $\mathrm{p}$ \\
\hline \multicolumn{13}{|l|}{ Participated? } \\
\hline Yes & $857(85.8)$ & $142(14.2)$ & 999 & & $219(25.6)$ & 635 (74.4) & 854 & & $904(94.5)$ & $53(5.5)$ & 957 & \\
\hline No & $265(86.3)$ & $42(13.7)$ & 307 & 0.81 & $65(24.6)$ & $199(75.4)$ & 264 & 0.74 & $292(97.0)$ & $9(3.0)$ & 301 & 0.07 \\
\hline No Answer & & & 26 & & & & 214 & & & & 74 & \\
\hline Total & $1122(84.2)$ & $184(15.8)$ & 1332 & & $284(21.3)$ & 834 (78.6) & 1332 & & 1196 (89.8) & $62(10.2)$ & 1332 & \\
\hline \multicolumn{13}{|l|}{ Age } \\
\hline$\leq 10$ years & $906(85.4)$ & 155 (14.6) & 1061 & & $221(24.5)$ & $681(75.5)$ & 902 & & $974(95.3)$ & $48(4.7)$ & 1022 & \\
\hline$>10$ years & $162(90.0)$ & $18(10.0)$ & 180 & 0.09 & 47 (29.2) & $114(70.8)$ & 161 & 0.21 & $165(94.5)$ & $10(5.7)$ & 175 & 0.56 \\
\hline No Answer & & & 91 & & & & 269 & & & & 135 & \\
\hline Total & $1068(80.2)$ & $173(19.8)$ & 1332 & & $268(20.1)$ & 795 (79.9) & 1332 & & $1139(85.5)$ & $58(14.5)$ & 1332 & \\
\hline
\end{tabular}

a Not considered in statistical test 
Table 2 - Students' perception on animal welfare, zoonoses and responsible pet ownership, according to number of participations in "Junior Vet" - Pinhais, Paraná - 2010

\begin{tabular}{|c|c|c|c|c|c|c|c|c|c|c|c|c|}
\hline & \multicolumn{4}{|c|}{$\begin{array}{c}\text { Animals have feelings and } \\
\text { emotions? }\end{array}$} & \multicolumn{4}{|c|}{$\begin{array}{c}\text { Do you know what is responsible } \\
\text { ownership? }\end{array}$} & \multicolumn{4}{|c|}{ Do you know what is zoonoses? } \\
\hline & Yes (\%) & No (\%) & Total & $\mathrm{p}$ & Yes (\%) & No (\%) & Total & $\mathrm{p}$ & Yes (\%) & No (\%) & Total & $\mathrm{p}$ \\
\hline 1 or 2 times & $798(96.1)$ & $32(3.9)$ & 830 & & $779(93.8)$ & $51(6.2)$ & 830 & & $506(62.2)$ & $307(37.8)$ & 813 & \\
\hline$>2$ times & $149(94.3)$ & $9(5.7)$ & 158 & 0.28 & $144(87.3)$ & $21(12.7)$ & 165 & 0.004 & $64(42.4)$ & $87(57.6)$ & 151 & 0.0001 \\
\hline No Answer ${ }^{\mathrm{a}}$ & & & 34 & & & & 27 & & & & 58 & \\
\hline \multirow[t]{3}{*}{ Total } & $947(92.6)$ & $41(73.4)$ & 1022 & & $910(89.0)$ & $70(10.9)$ & 1022 & & $570(55.8)$ & $394(44.2)$ & 1022 & \\
\hline & \multicolumn{4}{|c|}{$\begin{array}{c}\text { Did you change their way of } \\
\text { treating animals? }\end{array}$} & \multicolumn{4}{|c|}{$\begin{array}{c}\text { Do you feel more prepared to care } \\
\text { for a pet responsibly? }\end{array}$} & \multicolumn{4}{|c|}{ Did you comment with family? } \\
\hline & Yes (\%) & No (\%) & Total & $\mathrm{p}$ & Yes (\%) & No (\%) & Total & $p$ & Yes (\%) & No (\%) & Total & $\mathrm{p}$ \\
\hline 1 ou 2 times & $755(91,3)$ & $72(8,7)$ & 827 & & $764(94.8)$ & $42(5.2)$ & 806 & & $598(73.7)$ & $213(26.3)$ & 811 & \\
\hline$>2$ times & $139(88.0)$ & $19(12.0)$ & 158 & 0.19 & $144(92.3)$ & $12(7.7)$ & 156 & 0.22 & $101(66.9)$ & $50(33.1)$ & 151 & 0.08 \\
\hline No Answer ${ }^{\mathrm{a}}$ & & & 37 & & & & 60 & & & & 60 & \\
\hline \multirow[t]{3}{*}{ Total } & $894(87.4)$ & $91(12.6)$ & 1022 & & $908(88.8)$ & $54(11.2)$ & 1022 & & $699(68.4)$ & $263(31.6)$ & 1022 & \\
\hline & \multicolumn{4}{|c|}{ Do you have a dog/cat? } & \multicolumn{4}{|c|}{ Your pet has free street access? } & \multicolumn{4}{|c|}{$\begin{array}{l}\text { Do you know what is the best place for } \\
\text { a dog to live? }\end{array}$} \\
\hline & Yes (\%) & No (\%) & Total & $\mathrm{p}$ & Yes (\%) & No (\%) & Total & $\mathrm{p}$ & Yes (\%) & No (\%) & Total & $\mathrm{p}$ \\
\hline 1 ou 2 times & $704(85.3)$ & $121(14.7)$ & 825 & & $178(25.3)$ & $525(74.7)$ & 703 & & 751 (95.2) & $38(4.8)$ & 789 & \\
\hline$>2$ times & 139 (87.4) & $20(12.6)$ & 159 & 0.49 & $38(27.9)$ & $98(72.1)$ & 136 & 0.52 & $139(90.8)$ & $14(9.2)$ & 153 & 0.03 \\
\hline No Answer ${ }^{a}$ & & & 38 & & & & 183 & & & & 80 & \\
\hline Total & $843(82.4)$ & $141(17.5)$ & 1022 & & $216(21.1)$ & $623(78.8)$ & 1022 & & $890(87.1)$ & $52(12.9)$ & 1022 & \\
\hline
\end{tabular}




\section{Discussion}

In the present study, mostly fourth grade students (84.2\%) reported presence of dogs and/or cats in their homes (Table 1), corroborating with previous studies in which pets were more frequent in households with children (MURRAY et al., 2010; MARTINS et al., 2013). However, a higher frequency was observed herein when compared to the previously reported of $64.1 \%$ in Brazil (LIMA, A. M. A. et al., 2010) and $66.8 \%$ in England (WESTGARTH et al., 2013). Regardless, children may always benefit from the relationships with their pets and that looking after animals during childhood may contribute towards a more positive attitude to animals and human beings in adulthood (PODBERSCEK et al., 2006).

Although the majority of students (89.8\%) correctly answered that indoors and backyard was the most appropriate place for animals to live, $21.3 \%$ referred free access to the street by their pets (Table 1). A previous study in a different region of Brazil has shown similar results, with $30.6 \%$ of answers confirming pet free access to public streets (LIMA, F. F. et al., 2010). Another study in Australia has shown that households with gardens were more likely to own pets than other households, reflecting householders' desire to provide outside access for animals (MURRAY et al., 2010). Since probably the majority of children and their families have already incorporated the appropriate place for pets to live, no significant differences were observed between participating and non-participating groups. Programs of responsible ownership aiming to keep indoors and/or backyard pets may reduce the number of animals on the streets and prevent health-related problems and animal suffering. Therefore, these habits may be important to characterize a pet-friendly and responsible ownership culture in a given community (GARCIA et al., 2012).

The survey question approaching animal feelings and emotions was used to evaluate the children's perception of animal welfare, since animal feelings are reportedly an important part of their welfare
(BROOM; MOLENTO, 2004). Animal welfare may not be restricted to animal feelings (BROOM; MOLENTO, 2004), but may be an indicator of care perception of owners toward their pets. Hence, most students correctly answered this question (94.5\%) regardless of their participation in the contest (Table 1). These results reinforce the children's ability of considering and recognizing feelings and emotions on animals, facilitating educational activities focused on responsible pet ownership.

The majority of students ( $>92.0 \%$ in both groups) correctly answered about responsible pet ownership, with no statistical difference between participating and not-participating groups (Table 1). In contrast, a previous study in Australia has shown that children's knowledge of responsible pet ownership was higher for those given the educational program when compared to others (COLEMAN et al., 2008). Therefore, the findings of the present study suggest that responsible pet ownership concepts have been given outside the program (at home, for example). Nevertheless, practicing of pet responsible attitudes may produce strong healthy interactions between humans, animals and the environment, resulting in better individual, community and general quality of life.

Participating and non-participating students scored similarly (no statistical differences) on zoonosis concepts, with $41.1 \%$ and $35.7 \%$ mistakes, respectively (Table 1). This may represent a deficiency on given or absorbed information and may impair appropriate preventive measures. In a previous study, $71.8 \%$ of student parents were unable to correctly state what zoonoses were (LIMA, A. M. A. et al., 2010), contrasting with another study in which only $2 \%$ of adults had not heard of rabies and did not know that it could be transmitted by dogs (BINGHAM et al., 2010). Overall, teaching zoonoses to children should be improved in health educational programs as well as in student curriculum.

Teachers considered that contents given to the students was adequately transmitted at home as well, 
agreeing with $68.4 \%$ of students who mentioned commenting to relatives and friends. Hence, children may play a role as information multipliers and elementary schools may significantly act towards spreading and stimulating changes of attitude in their homes, as previously shown in Brazil (MAGALHÃES et al., 2009), United States (NICOLL et al., 2008) and Kenya (ONYANGO-OUMA et al., 2005).

Responsible pet ownership education may not endure and may be a challenge (COLEMAN et al., 2008), since students participating once or twice was significantly higher than participating more than two times on concepts (Table 2). Although these concepts may be short-term assimilated, more efforts to develop long-term educational strategies should be considered.

The present study has shown that students under 10 years of age significantly performed better on the concept of responsible ownership than older students (Table 2), indicating this age as an ideal one for teaching responsible ownership as given through Junior Vet Program. Besides, most students in the present study reported changing their way of treating animals after the Junior Vet program, similar to a previous study with children, showing a growing responsibility in caring for a dog at the same age (LOVE; OVERALL, 2001).

As limitations for the present study, questionnaires were self-applied to students and teachers and were not related each other; no differences were observed in participating or not in the program and volunteer participation of teachers was lower than the minimum sample. However, data was sufficient to obtain other conclusions when age and number of participating was applied. In addition, teacher participation may be critical to successful outcomes in health education projects (MAGALHÃES et al., 2009). Unfortunately, training participation (29.9\%) and use of available teaching materials $(26.9 \%)$ was a limiting factor in the present study and may have negatively impacted students' learning. Thus, development of effective strategies may be essential for training and commitment among teachers for changing attitudes and practices in order to disseminate and encourage responsible pet ownership. Finally, since educational programs on responsible pet ownership are still under development, involvement of veterinary professionals may represent an important source of information on pet ownership, zoonotic diseases, bite prevention and similar issues for owners and the general public (LOVE; OVERALL, 2001; BINGHAM et al., 2010; STULL et al., 2012).

In summary, perception of elementary school students on responsible pet ownership and related issues in an outreach education program was satisfactory due to the high percentage of correct answers in most evaluated questions. Participating once or twice in the program was sufficient for students to provide correct answers on evaluated concepts. In addition, an association was established between correct answer on pet responsible ownership concept and under 10 years of age. Thus, it may be suggested that a smaller number of education actions involving students in this age group may increase the number of participants or schools involved. Student age should be taken into account when planning educational activities for responsible pet ownership, animal welfare and zoonosis prevention, considering that most of the students evaluated in this study reported having animals. Pet educational programs should be periodically and continuously evaluated enabling detection, correction and adjustment, since younger students may be willing to change their attitudes and become effective pet responsible ownership multipliers for friends, relatives and general community. 


\section{References}

BARROS, C. C.; PAMPUCH, R.; BIONDO, A. W.; WOUK, A. F. P. F.; ANNUNZIATO, R. J.; AMORA JUNIOR, D. S.; CUNHA, G. R.; BRAGA, K. F.; SCZEPANSKI, B.; ALMEIDA, J. C. "Junior veterinary": a tool on young students education in health promoting and responsible custody and animal welfare in the County of Pinhais/PR. Veterinária em Foco, v. 6, n. 2, p. 179-184, 2009.

BINGHAM, G. M.; BUDKE, C. M.; SLATER, M. R. Knowledge and perceptions of dog-associated zoonoses: Brazos County, Texas, USA. Preventive Veterinary Medicine, v. 93, n. 2-3, p. 211-221, 2010. doi: http://dx.doi.org/10.1016/j.prevetmed.2009.09.019.

BROOM, D. M.; MOLENTO, C. F. M. Animal welfare: concept and related issues - Review. Archives of Veterinary Science, v. 9, n. 2, p. 1-11, 2004. doi: http://dx.doi.org/10.5380/avs.v9i2.4057.

CHAPMAN, S.; CORNWALL, J.; RIGHETTI, J.; SUNG, L. Preventing dog bites in children: randomised controlled trial of an educational intervention. British Medical Journal, v. 320 , n. 248 , p. 1512-1513, 2000. doi: http://dx.doi.org/10.1136/bmj.320.7248.1512.

COLEMAN, G. J.; HALL, M. J.; HAY, M. J. An evaluation of a pet ownership education program for school children. Anthrozoös, v. 21, n. 3, p. 271-284, 2008. doi: http://dx.doi.org/10.2752/175303708X332071.

FAVER, C. A. Sterilization of companion animals: exploring the attitudes and behaviors of latino students in South Texas. Journal of Applied Animal Welfare Science, v. 12, n. 4, p. 314-330, 2009. doi: http://dx.doi.org/10.1080/10888700903163534.

GARCIA, R. C. M.; CALDERÓN, N.; FERREIRA, F. Consolidation of international guidelines for the management of canine populations in urban areas and proposal of performance indicators. Revista Panamericana de Salud Pública, v. 32, n. 2, pt. 2, p. 140-144, 2012. Supplement 18. doi: http://dx.doi.org/10.1590/S1020-49892012000800008.

LIMA, A. M. A.; ALVES, L. C.; FAUSTINO, M. A. G.; LIRA, N. M. S. Perception of the zoonosis and responsible pet care by the parents from public schools kindergarten located at metropolitan region of Recife, northeast of Brazil. Ciência e Saúde Coletiva, v. 15, p. 1457-1464, 2010. Supplement 1. doi: http://dx.doi.org/10.1590/S1413-81232010000700057.

LIMA, F. F.; NETTO, L. C.; KOIVISTO, M. B.; PERRI, S. H. V.; BRESCIANI, K. D. S. Avaliação dos conceitos sobre posse responsável exercida pela terceira idade em instituições não governamentais de Araçatuba-SP. Revista Ciência em Extensão, v. 6, n. 2, p. 132-142, 2010.

LOVE, M.; OVERALL, K. L. How anticipating relationships between dogs and children can help prevent disasters. Journal of the American Veterinary Medical Association, v. 219, n. 4, p. 446-453, 2001. doi: http://dx.doi.org/10.2460/javma.2001.219.446.

MAGALHÃES, D. F.; SILVA, J. A.; HADDAD, J. P. A.; MOREIRA, E. C.; FONSECA, M. I. M.; ORNELAS, M. L. L.; BORGES, B. K. A.; LUZ, Z. M. P. Dissemination of information on visceral leishmaniasis from schoolchildren to their families: a sustainable model for controlling the disease. Cadernos de Saúde Pública, v. 25, n. 7, p. 16421646, 2009. doi: http://dx.doi.org/10.1590/\$0102$311 X 2009000700025$.

MARTINS, C. M.; MOHAMED, A.; GUIMARÃES, A. M. S.; BARROS, C. C.; PAMPUCH, R. S.; SVOBODA, W.; GARCIA, R. C. M.; FERREIRA, F.; BIONDO, A. W. Impact of demographic characteristics in pet ownership: modeling animal count according to owners income and age. Preventive Veterinary Medicine, v. 109, n 3-4, p. 213218, 2013.2 doi: http://dx.doi.org/10.1016/j.prevetmed.2012.10.006.

MOLENTO, C. F. M.; LAGO, E.; BOND, G. B. Population control of dogs and cats in ten Rural Villages in the State of Paraná, Brazil: mid-term results. Archives of Veterinary Science, v. 12, n. 3, p. 43-50, 2007. doi: http://dx.doi.org/10.5380/avs.v12i3.10926.

MURRAY, J. K.; BROWNE, W. J.; ROBERTS, M. A.; WHITMARSH, A.; GRUFFYDD-JONES, T. J. Number and ownership profiles of cats and dogs in the UK. Veterinary Record, v. 166, n. 6, p. 163-168, 2010. doi: http://dx.doi.org/10.1136/vr.b4712.

NICOLL, K.; TRIFONE, C.; SAMUELS, W. E. An in-class, humane education program can improve young students' attitudes toward animals. Society \& Animals Journal, v. 16, n. 1, p. 45-60, 2008. doi: http://dx.doi.org/10.1163/156853008X269881.

ONYANGO-OUMA, W.; AAGAARD-HANSEN, J.; JENSEN, B. B. The potential of schoolchildren as health change agents in rural western Kenya. Social Science \& Medicine, v. 61, n. 8, p. 1711-1722, 2005. doi: http://dx.doi.org/10.1016/j.socscimed.2005.03.041. 
PODBERSCEK, A. L. Positive and negative aspects of our relationship with companion animals. Veterinary Research Communications, v. 30, p. 21-27, 2006. Supplement 1. doi: http://dx.doi.org/10.1007/s11259-006-00050 .

STULL, J. W.; PEREGRINE, A. S.; SARGEANT, J. M.; WEESE, J. S. Household knowledge, attitudes and practices related to pet contact and associated zoonoses in Ontario,
Canada. British Medical Journal Public Health, v. 12, n. 553, 2012. doi: http://dx.doi.org/10.1186/1471-2458-12-553. WESTGARTH, C.; BODDY, L. M.; STRATTON, G.; GERMAN, A. J.; GASKELL, R. M.; COYNE, K. P.; BUNDRED, P.; MCCUNE, S.; DAWSON, S. Pet ownership, dog types and attachment to pets in 9-10 year old children in Liverpool, UK. British Medical Journal Veterinary Research, v. 9, n. 102, 2013. doi: http://dx.doi.org/10.1186/1746-6148-9-102. 